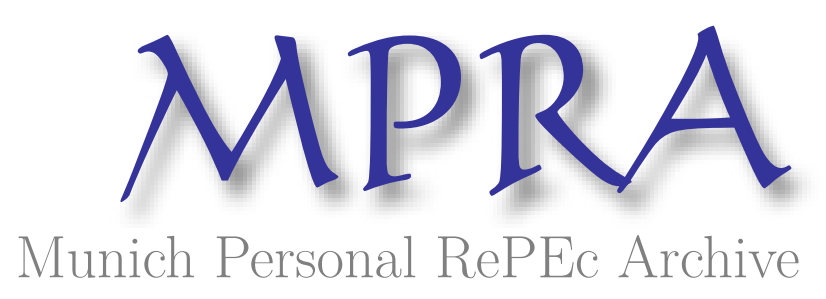

\title{
Bank Income Smoothing in South Africa: Role of Ownership, IFRS and Economic fluctuation
}

Ozili, Peterson K and Outa, Erick R

17 May 2018

Online at https://mpra.ub.uni-muenchen.de/102567/

MPRA Paper No. 102567, posted 26 Aug 2020 11:32 UTC 


\title{
Bank Income Smoothing in South Africa: \\ Role of Ownership, IFRS and Economic fluctuation
}

\author{
Peterson Ozili \\ $\&$
}

Erick Outa

This Version: September 2018 


\title{
Bank Income Smoothing in South Africa: \\ Role of Ownership, IFRS and Economic fluctuation
}

\begin{abstract}
We examine the determinants of the use of loan loss provisions to smooth income by banks in South Africa. More specifically, we examine the influence of ownership, IFRS disclosure rules and economic fluctuation on the income smoothing behaviour of South African banks while controlling for the traditional determinants of bank income smoothing via loan loss provisions. We find that South African banks do not use loan loss provisions to smooth income when they are (i) undercapitalised, (ii) have large non-performing loans and (iii) have a moderate ownership concentration. On the other hand, income smoothing is pronounced when South African banks are rather (iv) more profitable during economic boom periods, (v) well-capitalised during boom periods (iv) and is pronounced among banks that adopt IFRS and among banks with a Big 4 auditor. We also find that banks use loan loss provisions for capital management purposes, and bank provisioning is procyclical with economic fluctuations. Bank supervisors in South Africa should monitor the bank provisioning practices in South Africa closely to ensure that loan loss provisions are not used as a substitute bank capital. Banks in South Africa should not use sufficient provisioning as a substitute for sufficient bank capital. Secondly, the evidence for procyclical bank provisioning shows that provisioning by South African banks reinforce the current state of the economy and might compel bank supervisors in South Africa to consider the adoption of a dynamic provisioning system that is already adopted by bank supervisors in Spain, Peru, Uruguay, Colombia and Bolivia.
\end{abstract}

JEL classification: G01; G21; G28; M41

Keywords: Loan loss provisions, Income smoothing, Ownership, Economic Cycle, Earnings Management, Capital Management, IFRS. 


\section{Introduction}

Bank supervisors in South Africa require sufficient and timely recognition of loan loss provisions (LLPs) for South African banks while accounting standard setters in South Africa emphasise transparency in the way bank managers exercise their discretion in the determination of loan loss provisions estimates. The need for transparent, sufficient and timely loan loss provisioning became particularly important after South African banks were affected by the 2007-2009 global financial crisis which raised concern that the level of provisions by South African banks was not commensurate with the credit risk exposure of banks which led to speculations that bank provisions may be driven by other considerations other than credit risk considerations.

The banking literature show that bank managers have incentives to use loan loss provisions for other purposes rather than for credit risk management purposes, depending on the financial reporting outcomes that bank managers want (see Wall and Koch, 2000; Ozili and Outa, 2017; Ozili, 2018a,b). Also, the income smoothing literature show that banks have the ability to pursue additional management objectives such as income smoothing by overstating LLPs when earnings are too high and lowering LLPs when earnings are too low so that reported earnings is never too high or too low (see, Lobo and Yang, 2001; Laeven and Majnoni, 2003; Anandarajan et al, 2007; Leventis et al, 2011; Ozili and Outa, 2017), and such practice constitutes earnings management which reduces the reliability and informativeness of accounting numbers to shareholders and stakeholders, such as regulators and debtholders, who monitor bank behaviour.

Furthermore, bank ownership structure and strict disclosure rules can exert additional monitoring on bank behaviour. Arguably, banks with concentrated ownership (one or two controlling owners) could use LLPs to smooth income to conceal the extraction of private control benefits to controlling shareholders while income smoothing behaviour should be less pronounced among banks with a more dispersed ownership structure (Bouvatier et al, 2014). Also, strict disclosure regulation should limit the ability of bank managers to distort the financial reporting process to manipulate earnings if appropriate enforcement is ensured (Leventis et al, 2011; Outa et al, 2017). Given this backdrop, we examine whether ownership structure and disclosure rules exert some monitoring role on banks' ability to use LLP estimates to smooth income. We examine the case of South Africa.

Our study is important for the following reasons. One, there is a scant literature on the impact of ownership structure on bank earnings management, Bouvatier et al (2014) confirms this. By examining the case of a developing economy, we aim to provide some insight on how ownership structure influences the financial reporting characteristics of banks in a region considered to have relatively weak corporate governance mechanisms and poor disclosure regulation enforcement compared to developed countries. Moreover, there is currently no country-specific study that test the income smoothing hypothesis for the case of South African banks, therefore, our study aims to shed some light to understand whether the loan loss provisioning practices of South African banks is driven solely by credit risk considerations or by income smoothing considerations. Furthermore, because South Africa is considered to have a relatively well-developed banking system compared to other African countries (IMF, 2014) ${ }^{1}$, South Africa presents a natural setting to understand the loan loss provisioning practices of banks in a more developed African country. We predict and find no evidence to support the income smoothing hypothesis for South African banks. After controlling for capital management, LLPs are used to smooth income when banks are more profitable during economic boom periods, and among

\footnotetext{
${ }^{1}$ https://www.imf.org/external/pubs/ft/scr/2014/cr14338.pdf
} 
banks that adopt IFRS standard and among banks that have Big 4 auditor. We also observe that bank loan loss provisions are procyclical with economic cycle fluctuations.

Our study contributes to the extant literature. One, consistent with prior literature, our findings confirm that the propensity to use LLPs to smooth income depend on the unique conditions that banks face in a country and also depend on their opportunity. Secondly, by controlling for bank direct equity ownership, we contribute to the literature that examine the impact of ownership on earnings management among firms. We find that ownership control can influence the extent of bank earnings management that take the form of income smoothing via LLPs. Thirdly, by controlling for capital management incentives, our study contributes to the bank capital adequacy and stability literature that equate bank capital adequacy to bank stability (see Plantin, 2014; Ozili, 2017; Deli and Hasan, 2017; Ozili, 2018c). We show that well-capitalised banks report fewer provisions to smooth income, compared to under-capitalised banks. Furthermore, our study contributes to the accounting disclosure literature that examine the impact of IFRS and external audit quality on banks' reported earnings. The findings are useful to analysts, investors and other financial statement users in South Africa to help them reassess banks' reported earnings and how they use accounting numbers reported in bank financial reports. Finally, the study contributes to the global debate on the 'incurred-loss' provisioning model of banks and supports the argument that bank provisions are procyclical with economic cycle fluctuations because bank provisioning is backward-looking ${ }^{2}$ since it allows banks to delay provisioning until it is too late which further amplifies the current state of the economy.

The rest of the paper is organised as follows: Section 2 provides the theoretical framework. Section 2 also presents the contextual framework with a focus on loan loss provisioning in South Africa. Section 3 discuss the literature review and develops the hypotheses. Section 4 presents the data and methodology. Section 5 discuss the empirical results and Section 6 concludes.

\section{Theoretical and Contextual Framework}

\subsection{Theoretical Framework}

\subsubsection{Positive Accounting Theory}

Why do managers engage in earnings management practices? Positive accounting theory states that managers manage reported earnings because of explicit contracts given to them which are tied to accounting numbers. According to Watts and Zimmerman (1986), the main premise of positive accounting theory is that the accounting information generated by a firm is not merely a result of a firm's actions or operational activities but rather depends on the choice of accounting methods used to generate accounting information which in turn depends on explicit contracts given to firm managers. They argue that the explicit contracts given to managers motivate them to use specific accounting methods/techniques to manage earnings to meet financial reporting objectives that depend on the reported earnings number.

Positive accounting theory further argues that the explicit contracts given to managers will motivate them to use accounting methods to alter accounting information in order to (i) increase their bonuses (Watts and Zimmerman, 1986; 1990); (ii) to avoid debt covenant violation (Watts and Zimmerman, 1978; 1986); or (iii) to avoid the political costs associated with the size of reported earnings. The latter is predicated on the expectation that extremely high earnings can attract political criticism and

\footnotetext{
${ }^{2}$ See. Handorf and Zhu (2006)
} 
regulatory scrutiny, and such scrutiny is costly to firms; therefore, firm managers will have incentives to use accounting procedures that reduce high earnings in the current period which can be achieved by income smoothing to reduce the size of high earnings (Watts and Zimmerman, 1986).

\subsubsection{Income Smoothing and Positive Accounting Theory}

Income smoothing is a type of earnings management, and Lambert (1984) show that, under certain assumptions, the compensation scheme offered to managers can motivate them to smooth income to generate some desired level of earnings. He argues that: (i) the unobservability of managerial actions and (ii) the need to maximise the principal's utility and the agent's compensation jointly provide some incentive for managers to influence reported earnings via income smoothing, and the incentive to do so is stronger if managed earnings jointly maximises shareholders' wealth and increases the manager's likelihood of receiving the contractual compensation. Greenawalt and Sinkey (1988) extended Lambert's argument to the banking sector. They demonstrate that bank managers can smooth income to decrease high earnings during good years possibly to save up surplus earnings for the rainy day in anticipation of bad times, so that the surplus earnings can be used to increase low earnings during bad years to avoid reporting a loss during bad years. Furthermore, Ozili (2017c) also demonstrate that firms can smooth income by increasing low earnings when they expect losses in order to avoid sending a signal to regulators that the firm might fail if such signal could attract scrutiny of the firm's earnings by regulators and political commentators. Taking together, the theoretical arguments view income smoothing as a technique used by managers to meet managerial expectations, and to reduce high (low) earnings in good (bad) years so that reported earnings never seem to be too high or too low to attract regulatory or political scrutiny.

\subsection{Bank Provisioning in South Africa}

The South Africa Reserve Bank (SARB) is responsible for the regulation and supervision of banks in South Africa. ${ }^{3}$ In 2013, the SARB amended the banking regulation to be in line with Basel III capital framework to ensure that the banking system has sufficient capital to meet unexpected losses or shocks to the financial system in the South Africa. In 2004, the SARB made some adjustment to the existing banking regulation in line with Basel II in 2004 and require banks to include eligible provisions to Tier II capital. Eligible provisions include specific provisions, partial write-offs, country risk provisions and general provisions. ${ }^{4}$ In Basel II, banks were required to set aside loan loss provisions for actual loan default, highly probable loan default and loans that are past due for more than 90 days (see. Basel II paragraphs 452 and 453). However, the imprecise definition of what 'loan loss' entail is argued to create opportunities for South African bank managers to exercise their own judgement about whether specific loan losses are highly probable to default or less probable to default. Such discretion is also argued to encourage under-provisioning by banks in South Africa. Unsurprisingly, the PWC report states that a significant reduction in bank loan loss provisions contributed to increase the profitability of the biggest four banks in South Africa (PWC, 2010), ${ }^{5}$ raising some concern that the provisions of South African

\footnotetext{
${ }^{3}$ The "Banks Act, No. 94 of 1990, as amended in 2013" provide the enabling legislation that describe the minimum capital requirements for South Africa banks. The SARB enforced capital regulations to all 31 banks and banking groups domiciled in South Africa and loan loss provisions are included in the computation of minimum regulatory capital requirements.

${ }^{4}$ Specific provisions are set aside for actual loan default or a highly probable loan default while general provision is set aside for possible but yet unidentified loan losses. The inclusion of specific and general provisions to Tier II capital ratio which can create incentive for banks to under-provision to increase bank profit and capital levels. This is because specific provisions intended to mitigate expected losses would have some impact on bank earnings and capital.

${ }^{5}$ The Big Four South African banks are Absa, FirstRand, Nedbank and Standard Bank. PriceWatersCooper (PWC) report is available at: https://www.pwc.co.za/en/assets/pdf/major-banks-analysis-march-2011.pdf
} 
banks is not solely driven by credit risk considerations but rather by the need to smooth income to increase bank profits.

The incurred-loss provisioning model is the current model for the accounting for loss recognition in South Africa. The accounting for loan loss provisions is guided by IAS 39's incurred-loss model which allows significant managerial discretion in the determination of loan loss provision estimates. Under the incurred loss model, South African banks must recognise a loss on bank loan portfolio only when it is highly probable and/or when there is objective evidence that the loan cannot be repaid. This approach is criticised because it delays provisioning until it is too late. Critics argue that bank supervisors, responsible for assessing bank's credit risk, should rather require timely bank provisioning even before the loan loss materialises. These opposing views create conflict of interests between accounting rules and bank supervisory expectations. Regarding managerial discretion, the incurred loss model also allows banks to exercise significant discretion in the determination of loan loss provisions estimates and bank managers can exploit their discretion in order to delay, understate or overstate loan loss provisions to meet some defined reporting objectives tied to bank profit and capital.

\section{Literature Review and Hypothesis Development}

\subsection{Literature Review}

Income smoothing involves smoothing out the fluctuations in reported earnings over time (Bhat, 1996; Wall and Koch, 2000; Ozili and Outa, 2017). The literature suggests several reasons why managers may smooth reported earnings. Managers may smooth income to: protect their jobs (Fudenberg and Tirole, 1995; Watts and Zimmerman, 1990), reduce stock price volatility (Anandarajan et al, 2007), maximise firm value (Michelson et al, 2000), lower the cost of capital and borrowing costs (Dechow et al, 1995; Gebhardt et al, 2001), save for the rainy day (Greenawalt and Sinkey, 1988; Skala, 2015), and to reduce the risk perception of the firm (Bhat, 1996), etc.

Among financial institutions, the literature documents substantial evidence that loan loss provision is used to smooth income by financial institutions. Kanagaretnam et al (2004), El Sood (2012) and Kilic et al (2012) find evidence for income smoothing via LLPs among US banks. Ahmed et al (1999) examine whether US banks use LLPs for income smoothing, capital management or signalling purposes during the 1990 change in capital adequacy regulations. They find that LLPs were used for capital management purposes but not to smooth income. Similarly, Wetmore and Brick (1994) find no evidence for income smoothing among US banks.

Some studies show that the extent of income smoothing depends on economic incentives, circumstance of the bank, regulatory constraints, institutional quality and other country-level factors. For instance, Kanagaretnam et al (2003) show that bank managers smooth income when they need to raise capital as well as to protect their job. Liu and Ryan (2006) find that banks smooth income to reduce high earnings during the 1990 economic boom. Balbao et al (2013) find that bank income smoothing is pronounced when banks have positive and substantial earnings. Anandarajan et al (2007) show that bank income smoothing is pronounced among listed banks than non-listed banks in Australia because investors prefer smoother earnings than earnings surprise. Ozili (2018a) investigates the relationship between discretionary loan loss provisions and bank intangibles among African banks to understand whether banks increase (decrease) loan loss provisions in response to risks associated with investment in intangible assets. The study finds that loan loss provisions are inversely associated with bank intangible 
assets (and change in intangible assets), but the inverse association is weakened in environments with strong investor protection. The study also finds that income smoothing is reduced among banks that have large intangible asset investment, while income smoothing is pronounced among banks that have few intangible asset investments, but this behaviour is further reduced for banks in environments with strong minority shareholders right protection.

El Sood (2012) observe that US banks use LLPs to smooth income when they are more profitable and in non-recessionary periods while Kilic et al (2012) show that US banks use LLPs to smooth income when SFAS 133 disclosure regulation discourage banks from using derivatives and bank securities to manage earnings. Skala (2015) investigate banks in Central Europe and find that banks use LLPs to smooth earnings when they have high earnings possibly to save for the rainy day. Among insurance firms, Gaganis et al (2016) examine the role of technical reserves in the income smoothing behaviour of insurance companies. They examine 770 insurance firms operating in 87 countries over the period 2000 to 2009 period and find evidence for income smoothing, however, the extent of income smoothing is reduced among banks in countries that have better investor protection, strict regulation and supervision. Lim and Yong (2017) examine the effects of the revised Basel II rules on bank managers' discretion to smooth income via LLPs, and they find that under-capitalised banks engage in greater income smoothing while well-capitalised banks engage in less income smoothing during the Basel II period. In Europe, Ozili (2017a) investigate whether discretionary loan loss provisioning by Western European banks is driven by income smoothing or credit risk considerations in the post-financial crisis period and find that discretionary provisioning by Western European banks is driven by both income smoothing and credit risk considerations in the post-financial crisis period. Ozili and Thankom (2018) observe that European systemic banks use LLPs to smooth income, and they do so than non-systemic banks.

Studies from emerging economies also report mixed evidence for bank income smoothing via LLPs. For instance, Caporale et al (2017) examine the context of Italian banks. They examine 400 Italian banks for the period 2001 to 2012 and did not find evidence to support the income smoothing hypothesis. Wu et al (2015) examine 102 banks in China during the 2006 to 2011 period and find that banks with more foreign strategic investors use LLPs to smooth earnings than banks with fewer foreign strategic investors. Curcio et al (2014) test the income smoothing hypothesis and capital management hypothesis in China during the financial crisis and find that Chinese banks use LLPs to smooth bank earnings but not to manage capital levels. Bryce et al (2015) investigate the income smoothing, capital management and cyclical hypotheses for banks in Vietnam and did not find evidence for income smoothing among Vietnamese banks. Ozili (2015) find that listed banks in Nigeria use LLPs to smooth income, manage capital levels and to signal information about banks' prospects during voluntary IFRS adoption in Nigeria. Ozili (2017b) examine whether income smoothing by African banks is influenced by capital market considerations and the type of auditor while controlling for business cycle fluctuations. The study find evidence for income smoothing among listed banks and among banks with a Big-4 auditor. They also find that loan loss provisions are procyclical with business cycle fluctuations. They conclude that listed African banks smooth income because they are more visible to investors and that investors do not view stock price fluctuations as a good signal. Overall, the literature document some evidence for income smoothing via LLPs among banks in emerging countries; however, the literature has not extensively examined bank income smoothing incentives in the African context, and there is no in-depth analysis for South African banks. Desta (2017) examine the relationship between loan loss provision (LLP) and earnings management using a small sample of African commercial banks. From the 2004 to 2013 period and find a positive association between pre-managed earnings and discretionary LLP, supporting the income smoothing hypothesis. Fonseca and Gonzalez (2008) examine South African banks in their cross-country study but they did not examine the influence 
of ownership and IFRS rules on the income smoothing behaviour of South African banks. In contrast, our study undertakes an in-depth analysis of bank income smoothing in South Africa.

\subsection{Hypotheses development}

\subsubsection{Income Smoothing}

Lobo and Yang (2001) attribute a positive association between loan loss provisions and bank earnings before tax and provisions as evidence for managerial discretion to smooth earnings via loan loss provisions (LLPs) because bank managers can overstate LLP to lower high earnings and can understate LLP to increase low earnings, hence the income smoothing hypothesis. Liu and Ryan (2006), Kanagaretnam et al (2003), Kanagaretnam et al (2004), Bushman and William (2012) and Ozili (2017b) document evidence that banks use LLPs to smooth income and is consistent with the income smoothing hypothesis. Therefore, we follow prior empirical studies and re-investigate the income smoothing hypothesis for the case of South African banks. We predict that loan loss provisions are positively associated with bank earnings for South African banks.

H1: LLPs are positively associated with bank earnings before tax and LLPs for South African banks.

\subsubsection{Earnings and Economic Cycle}

Next, we refine the income smoothing hypothesis to test whether the incentive to smooth income is more pronounced when banks are more profitable during economic booms or recessionary periods. Watts and Zimmerman (1986) suggest that firms have incentives to lower high earnings to avoid excessive scrutiny of reported earnings by industry regulators while Liu and Ryan (2006) observe that more profitable US banks overstate LLPs to lower high earnings during the 1990 economic boom. Similarly, El Sood (2012) find that banks increase LLPs to smooth income when they are more profitable and when they are in non-recessionary period, and during the 2007-2009 financial crisis period possibly to minimise bank losses during the crisis period. Skala (2015) show that banks use LLPs to smooth earnings when they have high earnings as a strategy to save for the rainy day (i.e. recessionary periods). Accordingly, we predict that the use of LLPs to smooth income is more pronounced during boom periods and when banks are more profitable.

$\mathrm{H} 2$ : Income smoothing is positively associated with higher profitability and economic booms.

\subsubsection{Procyclicality}

The procyclical hypothesis predicts that bank provisioning is procyclical with economic fluctuations. To support the procyclical hypothesis, some studies examine the link between bank provisions and fluctuations in the economic cycle. For instance, Laeven and Majnoni (2003) and Handorf and Zhu (2006) argue that bank loan loss provisions are procyclical because the loan loss provisioning of most banks are backward-looking and exacerbate the current state of the economy. Bikker and Metzemakers (2005) demonstrate that, when significant losses hit the financial system of a country or the global economy, banks would respond by increasing LLP estimates which in turn would reduce bank profit and worsen the state of banks. If the recession is sustained for a prolonged period, increased provisioning would further reduce bank profits, deplete bank capital and worsen the existing recession. Olszak and Pipien (2016) examine the procyclicality of loan loss provisions in a cross-country analysis of 13 OECD countries during the 1995 to 2009 period and find that the procyclicality of LLP is significant almost for the whole sample of countries. Olszak et al (2017) investigate the relationship between loan loss provisions and the business cycle in the European union during the 1996 to 2011 period. They find that the loan loss provisions of large banks, publicly-traded banks, commercial banks, as well as banks reporting consolidated statements, are more procyclical. Their findings support the 
procyclical hypothesis. They also observe that neither official supervision nor private-market monitoring were effective in reducing the procyclicality of LLP. However, they observe that restrictive capital standards and better investor protection weakened the procyclicality of LLP. Ozili (2018b) examine the non-discretionary determinants of bank loan loss provisions in Africa after controlling for macroeconomic fluctuation, financial development and investor protection. The study finds that nonperforming loans, loan-to-asset ratio and loan growth are significant non-discretionary determinants of bank provisions in the African region. However, they also find that loan loss provisions are procyclical with macroeconomic fluctuation. de Haan and Van Oordt (2018) examine the timing of loan loss provisions during the crisis using supervisory micro data for 25 Dutch banks over the period 2008Q2 to 2014Q2. They find that banks, on average, aim for LLPs of $49 \%$ of impaired loans. In the short run, however, the adjustment of LLPs amounts to only $29 \%$ of the change of impaired loans, and the resulting deviation from the target is mostly made up by (a) provisioning more in subsequent quarters and (b) reversing lower amounts when loan losses do not materialize. By implication, their findings suggest that bank provisioning behaviour in the short-term is out of sync with their target levels.

Consistent with the literature (Laeven and Majnoni, 2003; Bikker and Metzemakers, 2005; Handorf and Zhu, 2006; Olszak and Pipien, 2016; Olszak et al, 2017; Ozili, 2018b), we predict that bank provisions are generally procyclical with economic cycle fluctuations. To be consistent with the literature, we use real gross domestic product growth rate to control for changing economic conditions.

H3: Loan loss provisions are negatively associated with GDP growth rate.

\subsubsection{Accounting Disclosure and External Audit quality}

IFRS adoption and the presence of Big 4 auditors can discourage the opportunistic manipulation of earnings by firm managers (Francis et al, 1999; Barth et al, 2008). Given that external audit quality is commonly associated with Big 4 audit firms, Francis et al (1999) argue that a firm would choose the services of a Big 4 auditor than non-Big 4 auditor if they believe that the reputation of Big 4 auditors reflects superior audit quality because Big 4 auditors are able to detect and are more willing to report material misstatements in financial statements thus discouraging opportunistic earnings manipulation. Kanagaretnam et al (2010) applied this idea to banks and investigate banks from 29 countries and find that both auditor-type and auditor industry specialization reduces the propensity to manage earnings to beat a benchmark. Ozili (2017b) examine whether income smoothing by African banks is influenced by capital market considerations and the type of auditor while controlling for business cycle fluctuations. The study find evidence for income smoothing among listed banks and among banks with a Big-4 auditor and conclude that the presence of Big 4 auditors did not reduce the extent of earnings management among African banks because Big-4 auditors were more concerned about penetrating the African audit market during the period of analysis.

Regarding IFRS adoption, the impact of IFRS adoption on earnings quality and accounting disclosure quality is mixed in the literature. For instance, Marton and Runesson (2017) focused on the predictive ability of bank loan loss provisions under IFRS and local GAAP and find that loan loss provisions in IFRS bank years predict future credit losses to a lesser extent than in local GAAP bank years. Gebhardt and Novotny-Farkas (2011) examines the implications of mandatory IFRS adoption on the accounting quality of banks in twelve EU countries. They analyse how the change in the recognition and measurement of banks' loan loss provision affects income smoothing behaviour and timely loss recognition. They find that the restriction to recognise only incurred losses under IAS 39 significantly reduces income smoothing, and this effect is less pronounced in countries with stricter bank supervision, widely dispersed bank ownership and for EU banks cross-listed in the US. Ahmed et al (2013) find evidence for increased income smoothing among firms that adopt IFRS. Similarly, Ozili (2015) find 
that banks smooth income during voluntary IFRS adoption period. On the other hand, Barth et al (2008) find evidence for reduced income smoothing among firms that voluntarily adopt IFRS. Leventis et al (2011) observe that the use of LLPs to smooth earnings among European listed banks is reduced after the implementation of IFRS. Consistent with Francis et al (1999), Barth et al (2008) and Kanagaretnam et al (2010), we refine the income smoothing hypothesis and predict that IFRS adoption and superior audit quality discourage income smoothing via LLPs among South African banks.

H4: Income smoothing via LLPs decreases with IFRS adoption and superior audit quality.

\subsubsection{Ownership}

Next, we refine the income smoothing hypothesis to examine whether bank income smoothing behaviour is influenced by bank ownership structure. La Porta et al (1999) argue that when large shareholders are involved in the decision-making process of a firm, the conflict of interest becomes centred on controlling owners versus minority shareholders rather than manager versus shareholders. Shleifer and Vishny (1997) argue that controlling shareholders impose greater monitoring on firm management and use their influence to compel managers to make decisions that increase overall shareholder value for the benefit to all shareholders. This view suggests that concentrated firm ownership align the interests of controlling shareholders with those of non-controlling ones by discouraging managerial opportunistic behaviour for the benefit of all. To support this view, Ozili and Uadiale (2017) show that firms with high ownership concentration have higher return on assets, higher net interest margin and higher recurring earning power while banks with dispersed ownership have lower return on assets. On the contrary, Shleifer and Wolfenzon (2002) demonstrate that the private benefits of control to controlling shareholders would rather entice controlling shareholders to extract corporate resources for private use, and the resulting loss in firm value due to their action would not be in the best interest of non-controlling or minority shareholders. This view suggests that concentrated firm ownership would encourage managerial opportunistic behaviour that increase private benefits to controlling shareholders at the expense of non-controlling shareholders. Further, Bouvatier et al (2014) also argue that controlling shareholders can elect their representative(s) to the board of directors who will appoint managers that will act in the interest of controlling shareholders, and the decision to manipulate earnings would depend on the trade-off between shared benefits of control and private benefit to controlling shareholders. In a recent study on the impact of ownership concentration on income smoothing, Bouvatier et al (2014) find evidence that bank income smoothing is more pronounced among banks with concentrated ownership and less pronounced among banks with dispersed ownership while Ozili and. Consistent with Shleifer and Wolfenzon (2002) and Bouvatier et al (2014), we predict that bank income smoothing is less pronounced among banks with dispersed ownership and more pronounced among banks with concentrated ownership.

H5: Income smoothing via LLP increases with concentrated ownership and decreases with dispersed ownership.

\section{Data and Method}

\subsection{Data}

Bank balance sheet and income statement information is obtained from Bankscope database (in USD). The sample period covers a 13-year period (2002 to 2014) and is long enough to cover a full economic cycle. Macroeconomic data for real gross domestic product growth rate is obtained from World Economic Forum archived in World Bank database. The population of the study include all banks in 
South Africa. To be included in the sample, a bank should have time-series annual data for loan loss provisions and should have at least 4-year consecutive data for crucial variables particularly loan loss provisions and the earnings variable. Hence, South African banks with fewer than 4-year consecutive data for crucial variables were excluded in order to control for the quality of bank financial reporting. The resulting sample yields 30 South African banks with available data. Furthermore, South African banks in our sample have unique characteristics. Some banks are listed and unlisted, some banks have Big 4 auditors and non-Big 4 auditors while other banks have varying ownership structure. The sample distribution is reported in Appendix A3.

\subsection{Methodology}

The baseline specification of the model is given as:

$$
\begin{gathered}
L L P i, t=\beta 0+\beta 1 E B T P i, t+\beta 2 N P L i, t+\beta 3 L O A N i, t+\beta 4 L O T A i, t+\beta 5 S I Z E i, t+\beta 6 C A P i, t \\
+\beta 7 \Delta G D P t+\beta j B A N K d u m m i e s i, t+\beta j P E R I O D d u m m i e s i, t+e i, t
\end{gathered}
$$

Where

'i' = bank

' $\mathrm{t}$ ' $=$ period

'n' = number of coefficients

'j’ $=1,2,3, \ldots . . n$

LLP $=$ loan loss provisions scaled by beginning total assets.

EBTP $=$ earnings before profit and tax scaled by beginning total assets.

$\mathrm{NPL}=$ non-performing/impaired loans scaled by beginning total assets.

LOAN = loan growth or change in gross loan outstanding

$\mathrm{CAP}=$ equity scaled by beginning total assets.

LOTA $=$ total loan scaled by beginning total assets .

SIZE $=$ natural logarithm scaled by beginning total assets.

$\Delta \mathrm{GDP}=$ change in real gross domestic product growth rate

BANKdummies $=$ bank level dummies to be interacted with EBTP variable

$\mathrm{e}=$ error term .

The model is a variation of the model adopted by Kanagaretnam et al (2003), Leventis et al (2011), El Sood (2012) and Ozili (2017b). The main variable of interest is the association between LLP and EBTP. Consistent with prior studies, we predict a positive sign for EBTP coefficient as evidence for the use of LLPs to smooth income. Additionally, we test whether income smoothing behaviour is more pronounced when banks are more profitable. To capture substantial profitability levels, we introduce two dummy variables: POS and HIGH where POS equal one if EBTP is positive and zero otherwise, to reflect non-negative earnings while HIGH equal one if EBTP is above-the-median EBTP and zero otherwise, to capture periods when banks are more profitable earnings. EBTP is then interacted with POS and HIGH to detect whether income smoothing is more pronounced when banks are more profitable. 
$\Delta$ GDP variable captures procyclical provisioning, i.e., bank provisioning in response to fluctuations in the economic cycle. Laeven and Majnoni (2003) and Bikker and Metzemakers (2005) show that, during recessionary periods, banks will keep more provisions and will keep fewer provisions during periods of economic prosperity. To capture economic cycle fluctuation, we use real gross domestic product growth rate and this approach is consistent with Laeven and Majnoni (2003), Bikker and Metzemakers (2005) and Ozili (2018b). Also, in line with Liu and Ryan (2006) and El Sood (2012), we test whether bank income smoothing is more pronounced during economic recession or boom periods. We introduce two dummy variables: REC and BOOM. REC variable equal one if $\triangle$ GDP is negative and zero otherwise, representing recessionary periods (or economic downturns) while BOOM variable equal one if $\triangle \mathrm{GDP}$ is above-the-median $\triangle \mathrm{GDP}$ and zero otherwise, representing periods of economic boom (or economic upturns). REC and BOOM are then interacted with EBTP to detect whether bank income smooth is more pronounced during recessions or booms. The regression models to test for the second hypothesis is given as:

$$
\begin{aligned}
L L P i, t=\beta 0+ & \beta 1 E B T P i, t+\beta 2 N P L i, t+\beta 3 L O A N i, t+\beta 4 L O T A i, t+\beta 5 S I Z E i, t+\beta 6 C A P i, t \\
& +\beta 7 \triangle G D P t+\beta 8 R E C i, t+\beta 9 R E C * E B T P i, t+\beta 10 B O O M i, t+\beta 11 \text { BOOM } \\
& * E B T P i, t+\beta 12 P O S i, t+\beta 13 P O S * E B T P i, t+\beta 14 H I G H i, t+\beta 15 H I G H \\
& * E B T P i, t+\beta 16 B O O M * P O S * E B T P i, t+\beta 17 B O O M * H I G H * E B T P i, t+e i, t
\end{aligned}
$$

Also, we include CAP variable to capture the use of LLPs to manage bank capital levels. Bonin and Kosak (2013) demonstrate that, if banks view loan loss provisions as a form of capital, banks will overstate LLPs to compensate for their low capital levels and understate LLPs when capital levels are high, implying a negative sign for CAP coefficient. Additionally, we test whether income smoothing behaviour is more pronounced when banks are under-capitalised or well capitalised. To do this, we introduce the UC dummy variable that take the value of one if CAP ratio is less than $25 \%$ and zero otherwise and WC dummy variable that take the value of one if CAP ratio at least $50 \%$ and zero otherwise.

Regarding the control variables, prior studies isolate the discretionary components of provisions from its non-discretionary components or determinants (e.g. Leventis et al, 2011; El Sood, 2012; Ozili, 2015). Consistent with prior studies, we use four variables to control for non-discretionary determinants of bank provisions: NPL, LOAN and LOTA. LOTA reflects the default risk of bank loan portfolio. Banks with higher loan to asset ratio have higher default risk and will keep more provisions to mitigate their default risk (Fonseca and Gonzalez, 2008), implying a positive relationship between LLP and LOTA. LOAN captures bank provisioning in response to contemporaneous credit risk on the overall loan portfolio (Fonseca and Gonzalez, 2008), however, we do not have a definite prediction for the LOAN variable. Additionally, NPL captures bank provisioning in response to loan loss on bank loan portfolio. Beaver and Engel (1996) demonstrate that banks will keep more provisions when they expect higher loan losses, therefore, a positive sign for NPL coefficient is expected. Additionally, we test whether the propensity to use LLPs to smooth earnings is more pronounced when banks have significant nonperforming loans. To do this, we use a simple criterion based on the idea that managers will try to avoid reporting double-digit NPL ratios. ${ }^{6}$ DB dummy variable is introduced and equal one if NPL ratio is a double-digit number (when expressed as a percentage) and zero otherwise, representing periods when banks have high non-performing loan. DB is then interacted with EBTP to test whether income smoothing via provisions is more pronounced when banks expect significant loan losses. SIZE variable is the natural logarithm of total assets. Anandarajan et al (2007) suggest that large banks have high level

\footnotetext{
${ }^{6}$ As a rule of thumb, bank managers and board of directors do not view double-digit NPLs as a good signal for asset quality of a bank.
} 
of business activities and will keep higher provisions that is commensurate with their increased level of business activities; hence, a positive sign for the SIZE coefficient is predicted. The extended regression model is given as:

$$
\begin{aligned}
L L P i, t=\beta 0+ & \beta 1 E B T P i, t+\beta 2 N P L i, t+\beta 3 L O A N i, t+\beta 4 L O T A i, t+\beta 5 S I Z E i, t+\beta 6 C A P i, t \\
& +\beta 7 \Delta G D P t+\beta 8 U C i, t+\beta 9 U C i, t * E B T P i, t+\beta 10 W C+\beta 11 W C * E B T P i, t \\
& +\beta 12 D B i, t+\beta 13 D B * E B T P i, t+e i, t
\end{aligned}
$$

To test whether earnings smoothing is significantly influenced by ownership, we introduce three dummy variables to capture three levels of bank ownership. DISP is a dummy variable that take the value of one if no majority shareholder of a bank holds more than $40 \%$ direct equity holding and zero otherwise, representing banks with a more dispersed ownership structure. CN1 is a dummy variable that take the value of one if a bank's majority shareholder has at least $40 \%$ but less than $70 \%$ of direct equity holdings and zero otherwise, representing majority shareholders with moderate control. CN2 is a dummy variable that take the value of one if the bank has a majority shareholder that has at least $70 \%$ direct equity holdings (i.e. $70 \%$ to $100 \%$ ) and zero otherwise, representing banks with a more concentrated ownership structure. DISP, CN1 and CN2 are interacted with EBTP to detect whether varying degree of ownership structure influence bank earnings smoothing behaviour. The regression model to test for the impact of ownership control is given as:

$$
\begin{aligned}
L L P i, t=\beta 0+ & \beta 1 E B T P i, t+\beta 2 N P L i, t+\beta 3 L O A N i, t+\beta 4 L O T A i, t+\beta 5 S I Z E i, t+\beta 6 C A P i, t \\
& +\beta 7 \triangle G D P t+\beta 8 D I S P i, t+\beta 9 D I S P * E B T P i, t+\beta 10 C N 1 i, t+\beta 11 C N 1 \\
& * E B T P i, t+\beta 12 C N 2 i, t+\beta 13 C N * E B T P i, t+e i, t
\end{aligned}
$$

Regarding accounting disclosure and external quality, we test whether banks that adopt IFRS standards and banks with Big 4 auditor exhibit more or less income smoothing behaviour. To capture this, we introduce DQ dummy variable that take the value of one if a bank adopts IFRS standard and zero otherwise, and a BIG4 variable that take the value one if the bank has a Big 4 auditor and zero otherwise, representing banks that have a Big-4 auditor which is often associated with superior audit quality. Further tests investigate the impact of the financial crisis on bank income smoothing behaviour. El Sood (2012) observe that banks smooth income in the pre-crisis period. We extend El Sood (2012)'s analysis and test whether the pre- and post-financial crisis period had a significant impact on the way banks use LLPs to smooth income ${ }^{7}$. The CRISIS dummy variable is introduced and equal one for the post-crisis period (i.e., 2009, 2010, 2011, 2012, 2013 and 2014) and zero otherwise. Additionally, we test whether income smoothing is pronounced among listed firms in South Africa. Anandarajan et al (2007) and Leventis et al (2011) argue that listed firms can smooth income to reduce the fluctuations in stock prices. We introduce LISTED variable that equal one if the bank is listed and zero otherwise.

$$
\begin{aligned}
\text { LLPi, } t=\beta 0+ & \beta 1 E B T P i, t+\beta 2 N P L i, t+\beta 3 L O A N i, t+\beta 4 L O T A i, t+\beta 5 S I Z E i, t+\beta 6 C A P i, t \\
& +\beta 7 \triangle G D P t+\beta 8 D Q i, t+\beta 9 D Q * \text { EBTP }, t+\beta 10 B I G 4 i, t+\beta 11 B I G 4 \\
& * \text { EBTPi,t }+\beta 12 \text { LISTEDi,t }+\beta 13 \text { LISTED } * \text { EBTPi, } t+\beta 14 \text { CRISISi }, t \\
& +\beta 13 \text { CRISIS } * \text { EBTP } i, t+e i, t
\end{aligned}
$$

We use ordinary least square (OLS) panel estimation with bank fixed effects to account for bankspecific differences in South Africa, to ensure that the reported significance levels are not driven by

\footnotetext{
${ }^{7}$ During the 2007 to 2008 global financial crisis, African banks were perceived to be less systemically interconnected with the global financial system particularly. Therefore, there is the expectation that pre-and post-crisis analysis may not yield any significant difference in the results. However, South African banks are also considered to be the most internationally-active banks in Africa compared to banks in other African countries. This is the justification for considering a pre- and post-crisis analysis for the case of South Africa.
} 
cross-sectional dependence in the residuals. However, bank fixed effects are not included to estimate models where cross-section binary dummies are perfectively collinear with the bank fixed-effect dummies. All standard errors are clustered by bank and year and is robust to heteroscedasticity issues. Finally, separate regressions are used to estimate the model rather than single regressions with sandwiched variables. The variable descriptions are reported in Appendix A5.

\section{Empirical Results}

Descriptive statistics are reported in Appendix A1 and show that LLPs for South African banks are, on average, $2.2 \%$ while EBTP is 5.6\%. The correlation matrixes are reported in Appendices A2 and A4. The correlation results in A2 reports a positive and significant correlation between LLP and EBTP indicating evidence for income smoothing. Also, the correlation between LLP and NPL is positively significant and indicates that higher problems loans is followed by higher bank provisions. In addition, the significant and positive correlations between LLP and both LOAN, LOTA and CAP suggest that loan loss provisions are sensitive to bank lending, loan-to-asset composition and bank capital levels. Finally, the correlation between LLP and SIZE is negative and significant while the correlation with LLP and $\triangle$ GDP are negative and statistically insignificant. Overall, the correlation coefficients of the explanatory variables are sufficiently low and suggest that multicollinearity is not an issue in the analyses.

\section{[Appendix A1 and A2]}

\subsection{Regression Results}

\subsubsection{Income smoothing hypothesis}

The results are reported in Column 1 of Table 1. For the full sample in Column 1, EBTP coefficient is positive but insignificant indicating a weak positive relationship between LLP and EBTP and implies that there is no significant evidence for income smoothing. The finding is inconsistent with the income smoothing hypothesis and supports the findings of Ahmed et al (1999) and Wetmore and Brick (1994).

CAP coefficient is negatively significant indicating that LLPs are used to manage bank capital levels and is consistent with Bonin and Kosak (2013), implying that South African banks view LLPs as a form of bank capital and will increase (or decrease) LLPs when bank capital is low (or high). Also, $\triangle$ GDP coefficient is negatively significant in Column 1, and implies that banks lower LLPs during good economic periods and keep higher LLPs during bad economic periods and is consistent with Laeven and Majoni (2003) and Bikker and Metzemakers (2005). This finding suggests that bank provisioning in South Africa is procyclical with fluctuations in the economic cycle. Regarding other control variables in Column 1, NPL coefficient is positively significant indicating that banks increase LLPs when they expect higher non-performing loans. Similarly, LOTA coefficient is positively significant indicating that banks increase LLPs when they face higher default risk. LOAN coefficient is insignificant. SIZE coefficient is negatively significant implying that large South African banks report fewer loan loss provisions.

\section{[Insert Table 1]}

\subsubsection{Transient Earnings and Economic Incentives}

To test whether banks' incentive to smooth income is pronounced when banks are more profitable, the POS*EBTP and HIGH*EBTP coefficients are insignificant in Column 2 and 3 of Table 1 and indicate that income smoothing behaviour is not pronounced when banks are more profitable. Similarly, 
BOOM*EBTP and REC*EBTP coefficients are insignificant in Column 4 and 5 and indicate that income smoothing behaviour is not significantly pronounced during boom or recessionary periods. Moreover, from theory, we understand that banks are more profitable during economic booms periods and less profitable during recessionary periods. To capture increased profitability during boom periods, the variable of interest is the interaction between EBTP, the profitability dummies 'POS' and 'HIGH' and economic boom 'BOOM' variables in Column 6 and 7. BOOM*HIGH*EBTP coefficient is positively significant at the $5 \%$ level indicating that South African banks use LLPs to smooth income when they are more profitable during economic boom periods possibly to lower high earnings during boom periods to avoid excessive scrutiny of high reported earnings by bank supervisors. Liu and Yang (2006) and El Sood (2012) also find similar evidence for the case of US banks. BOOM*POS*EBTP coefficient is insignificant.

\section{[Table 1]}

\subsubsection{Ownership, Disclosure Rules and Audit Quality}

Column 1 to 3 of Table 2 reports the impact of ownership on bank income smoothing. DISP*EBTP coefficient is positive but insignificant suggesting that disperse ownership concentration does not have a significant impact on bank income smoothing via provisions for South African banks. CN1*EBTP coefficient is negatively significant in Column 2 indicating that the use of LLPs to smooth income is significantly reduced or less pronounced among South African banks with moderate ownership concentration, i.e., banks where a majority shareholder hold up to $50 \%$ to $69 \%$ direct equity holdings. The finding is consistent with Shleifer and Vishny (1986) who posit that controlling shareholders use their influence to discourage managers from opportunistic behaviour to increase the benefit to all shareholders including minority shareholders. CN2*EBTP coefficient is insignificant in Column 3. For disclosure regulation and audit quality, DQ*EBTP coefficient is positively significant in Column 4 indicating that the use of LLPs to smooth income is more pronounced among banks that adopt IFRS and this finding is consistent with Ahmed et al (2013), implying that either the increased flexibility permitted by IFRS or weak enforcement of IFRS in South Africa create opportunities for banks to opportunistically use LLPs to smooth their reported earnings. BIG4*EBTP coefficient is positively significant in Column 5 indicating that the use of LLPs to smooth income is pronounced among banks that have Big 4 auditor relative to banks that have a non-Big 4 auditor, implying that the presence of Big 4 auditors did not discourage earnings management that take the form of earnings smoothing. LISTED*EBTP coefficient is insignificant in Column 6 and is inconsistent with Leventis et al (2011) and do not support the view that listed firms can smooth earnings to minimise stock price fluctuations (Anandarajan et al, 2007). CRISIS*EBTP coefficient is insignificant in Column 7 and indicate that bank income smoothing via LLP is not significantly different in the post-crisis period relative to the pre-crisis period.

[Table 2]

\subsubsection{Further Tests}

Further, we test whether South African banks' incentive to smooth income is driven by the magnitude of loan loss and bank capital considerations. The result is reported in Table 3. DB*EBTP coefficient is negatively significant in Column 1 and indicate that banks do not use LLPs to smooth income when they have high problem loans, implying that South African banks' LLPs accurately reflect credit risk decisions rather than income smoothing considerations when banks have abnormal or large NPLs. UC*EBTP coefficient is negatively significant in Column 2 indicating that the propensity to smooth income via LLPs is reduced when banks are undercapitalised. This imply that banks with less than $25 \%$ 
equity capital have less incentive to use LLPs to smooth income. On the other hand, WC*EBTP coefficient is positively significant at the $10 \%$ level in Column 3 indicating that the propensity to smooth income via LLP is pronounced when South African banks are well-capitalised, implying that banks with at least $50 \%$ equity capital have some incentive to use LLP to smooth income. Furthermore, we perform a two-way interaction and observe that BOOM*WC*EBTP coefficient is positively significant in Column 4, implying that well-capitalised South African banks use LLPs to smooth income during economic boom periods while REC*UC*EBTP coefficient is insignificant in Column 5.

[Table 3]

\section{Conclusion}

We examined the determinants of the use of loan loss provision to smooth income in the case of South Africa - an emerging market, a context that has not been extensively explored in the extant literature. We focus on the impact of ownership, IFRS disclosure rules and economic fluctuation on the income smoothing behaviour of South African banks. We find that the propensity to smooth income by South African banks is pronounced: (i) when banks are more profitable during economic boom periods, (ii) when banks are well-capitalised during economic booms. Income smoothing is also pronounced among banks with a Big 4 auditor and for banks that adopt IFRS reporting standards. However, the propensity to smooth income is significantly reduced (i) when banks have moderate ownership concentration and when banks are undercapitalised. The findings also show that bank provisioning in South Africa is procyclical with business cycle fluctuations.

The policy implication for bank supervisors in South Africa are two-fold. One, the evidence for capital management suggest that South African banks use LLP estimates as a form of capital to compensate for their low capital levels. Loan loss provisions are intended to cover for expected loan loss and not for capital management purposes while bank capital is intended to cover unexpected loan loss of banks. Bank supervisors in South Africa should monitor the bank provisioning practices in South Africa closely to ensure that loan loss provisions are not used as a substitute bank capital. Banks in South Africa should not use sufficient provisioning as a substitute for sufficient bank capital. Secondly, the evidence for procyclical bank provisioning signal that provisioning by South African banks reinforce the current state of the economy and might compel bank supervisors in South Africa to consider the adoption of a dynamic provisioning system that is already adopted by bank supervisors in Spain, Peru, Uruguay, Colombia and Bolivia.

The study has limitations which also presents some direction for future research. One limitation of the study is the focus on loan loss provision as the income smoothing tool used by South African banks. Although our focus on loan loss provision as the income smoothing tool used banks is widely supported in the banking literature (see literature review), loan loss provision is not the only accounting number that bank managers can use to smooth reported earnings; they can use a combination of accounting numbers depending on their opportunity such as commission and fee income (see Ozili, 2017d); therefore, future research can investigate the alternative accounting numbers used by banks to smooth income. Another limitation of the study is that banks may not rely solely on income smoothing to manage reported earnings. Depending on the circumstance of the bank, bank managers in South Africa can employ other earning management strategies such as income-increasing earnings management and big-bath earnings management; therefore, future research should investigate the earnings management practices of South African banks. Another limitation of the study is that we did not consider the influence of financial development on managerial discretion in financial reporting in South Africa. 
Future research could investigate whether the level of financial development in South Africa has an impact on banks' incentive to smooth income in financial reporting.

\section{Reference}

Ahmed, A., Takeda, C., and Thomas, S. (1999). Bank loan loss provisions: A re-examination of capital management, earnings management, and signalling effect. Journal of Accounting and Economics, Vol.28 No 1, pp. 1-25.

Ahmed, A. S., Neel, M., and Wang, D. (2013). Does mandatory adoption of IFRS improve accounting quality? Preliminary evidence. Contemporary Accounting Research, Vol 30 No. 4, pp. 1344-1372.

Anandarajan, A., Hasan, I., and McCarthy, C. (2007). Use of loan loss provisions for capital, earnings management and signalling by Australian banks. Accounting and Finance Vol. 47 No. 3, pp. 357-379.

Balboa, M., López-Espinosa, G., and Rubia, A. (2013). Nonlinear dynamics in discretionary accruals: An analysis of bank loan-loss provisions. Journal of Banking and Finance, Vol. 37 No. 12, pp. 51865207.

Barth, M., Landsman, W. and Lang, M. (2008). International accounting standards and accounting quality", Journal of Accounting Research, Vol 46 No. 3, pp. 467-498.

Beaver, W. H., and Engel, E. E. (1996). Discretionary behavior with respect to allowances for loan losses and the behavior of security prices. Journal of Accounting and Economics, Vol 22 No.1, pp. 177206.

Bhat, V. N. (1996). Banks and income smoothing: an empirical analysis. Applied Financial Economics, Vol 6 No 6, pp. 505-510.

Bikker, J., and Metzemakers, P. (2005). Bank provisioning behavior and procyclicality. International Financial Market, Institutions, and Money, Vol 15 No. 2, pp. 141-157.

Bryce, C., Dadoukis, A., Hall, M., Nguyen, L., and Simper, R. (2015). An analysis of loan loss provisioning behaviour in Vietnamese banking. Finance Research Letters, Vol 14, pp. 69-75.

Bonin, J., and Kosak, M. (2013). Loan Loss Provisioning in Emerging Europe: Precautionary or ProCyclical? Department of Economics Working Paper No. 10. Wesleyan University.

Bouvatier, V., Lepetit, L., and Strobel, F. (2014). Bank income smoothing, ownership concentration and the regulatory environment. Journal of Banking and Finance, Vol 41, pp. 253-270.

Bushman, R. M., and Williams, C. D. (2012). Accounting discretion, loan loss provisioning, and discipline of banks' risk-taking. Journal of Accounting and Economics, Vol 54 No. 1, pp. 1-18.

Caporale, G. M., Alessi, M., Di Colli, S., and Lopez, J. S. (2015). Loan Loss Provision: Some Empirical Evidence for Italian Banks. DIW Berlin Discussion Paper No. 1459. Available at SSRN: http://ssrn.com/abstract=2576711 or http://dx.doi.org/10.2139/ssrn.2576711

Curcio, D., Dyer, D., Gallo, A., and Gianfrancesco, I. (2014). Determinants of banks' provisioning policies during the crisis: Evidence from the Chinese banking system. Managerial Finance, Vol 40, No 10, pp. 987-1006. 
Dechow, P. M., Sloan, R. G., and Sweeney, A. P. (1995). Detecting earnings management. The Accounting Review, Vol. 70, No. 2, pp. 193-225.

Deli, Y. D. and Hasan, I. (2017), "Real effects of bank capital regulations: Global evidence”, Journal of Banking and Finance, Vol. 82, pp. 217-228.

de Haan, L., and Van Oordt, M. R. (2018). Timing of banks' loan loss provisioning during the crisis. Journal of Banking and Finance, Vol 87, 293-303.

Desta, T. S. (2017). Consequence of loan loss provisions on earnings management behaviour: A study on the best African commercial banks. South African Journal of Business Management, Vol. 48 No.3, pp. 1-11.

El Sood, H. A. (2012). Loan loss provisioning and income smoothing in US banks pre and post the financial crisis. International Review of Financial Analysis, Vol 25, pp 64-72.

Fonseca, A. R., and González, F. (2008). Cross-country determinants of bank income smoothing by managing loan-loss provisions", Journal of Banking and Finance, Vol 32 No. 2, pp.217-228.

Francis, J. R., and Krishnan, J. (1999). Accounting Accruals and Auditor Reporting Conservatism. Contemporary Accounting Research, Vol 16 No1, pp. 135-165.

Fudenberg, D., and Tirole, J. (1995). A theory of income and dividend smoothing based on incumbency rents. Journal of Political Economy, Vol 103, No.1, pp. 75-93.

Gaganis, C., Hasan, I., and Pasiouras, F. (2016). Regulations, institutions and income smoothing by managing technical reserves: international evidence from the insurance industry. Omega, Volume 59, Part A, 113-129.

Gebhardt, W. R., Lee, C., and Swaminathan, B. (2001). Toward an implied cost of capital. Journal of Accounting Research, Vol 39 No.1 pp. 135-176.

Gebhardt, G. U., and Novotny-Farkas, Z. (2011). Mandatory IFRS adoption and accounting quality of European banks. Journal of Business Finance and Accounting, Vol. 38 No (3-4), 289-333.

Greenawalt, M. B., and Sinkey Jr, J. F. (1988). Bank loan-loss provisions and the income-smoothing hypothesis: an empirical analysis, 1976-1984. Journal of Financial Services Research, Vol 1 No. 4, pp. 301-318.

Handorf, W., and Zhu, L. (2006). U.S. bank loan-loss provisions, economic conditions, and regulatory guidance. Journal of Applied Finance, Vol 16 No1, pp. 97-113.

IMF, (2014). South Africa: Article IV Consultation Report. Available at: https://www.imf.org/external/pubs/ft/scr/2014/cr14338.pdf (Accessed on 12th April, 2016)

Kanagaretnam, K., Lobo, G., and Mathieu, R. (2003). Managerial incentives for income smoothing through bank loan loss provisions. Review of Quantitative Finance and Accounting, Vol 20 No1, pp. 63-80.

Kanagaretnam, K., Lobo, G., and Yang, D. (2004). Joint tests of signaling and income smoothing through bank loan loss provisions", Contemporary Accounting Research, Vol 21No 4, pp. 843-844.

Kanagaretnam, K., Krishnan, G. V., and Lobo, G. J. (2010). An empirical analysis of auditor independence in the banking industry", The Accounting Review, Vol 85 No 6, pp. 2011-2046. 
Kilic, E., Lobo, G. J., Ranasinghe, T., and Sivaramakrishnan, K. (2012). The impact of SFAS 133 on income smoothing by banks through loan loss provisions. The Accounting Review, Vol. 88 No.1, pp. 233-260.

La Porta, R., Lopez-de-Silanes, F., and Shleifer, A. (1999). Corporate ownership around the world. The Journal of Finance, Vol 54 No. 2, pp. 471-517.

Laeven, L., and Majnoni, G. (2003). Loan loss provisioning and economic slowdowns: Too much, too late”, Journal of Financial Intermediation, Vol 12 No. 2, pp. 178-197.

Lambert, R. A. (1984). Income smoothing as rational equilibrium behavior. The Accounting Review, Vol. 59, No. 4, pp. 604-618.

Leventis, S., Dimitropoulos, P. E., and Anandarajan, A. (2011). Loan loss provisions, earnings management and capital management under IFRS: The case of EU commercial banks. Journal of Financial Services Research, Vol 40 No (1-2), pp. 103-122.

Lim, C. Y., and Yong, K. O. (2017). Regulatory pressure and income smoothing by banks in response to anticipated changes to the Basel II Accord. China Journal of Accounting Research, Vol 10 No. 1, pp. 9-32.

Liu, C., and Ryan, S. (2006). Income smoothing over the business cycle: Changes in banks' coordinated management of provisions for loan losses and loan charge-offs from the pre-1990 bust to the 1990s boom. The Accounting Review. Vol 81 No.2, pp. 421-441.

Lobo, G. J., and Yang, D. H. (2001). Bank managers' heterogeneous decisions on discretionary loan loss provisions. Review of Quantitative Finance and Accounting, Vol 16 No.3, pp. 223-250.

Marton, J., and Runesson, E. (2017). The predictive ability of loan loss provisions in banks-Effects of accounting standards, enforcement and incentives. The British Accounting Review, Vol. 49 No. 2, pp. $162-180$.

Michelson, S. E., Jordan-Wagner, J., and Wootton, C. W. (2000). The relationship between the smoothing of reported income and risk-adjusted returns. Journal of Economics and Finance, Vol 24 No 2, pp. 141-159.

Olszak, M., and Pipień, M. (2016). Cross-country linkages as determinants of procyclicality of loan loss provisions. The European Journal of Finance, Vol 22 No. 11, pp. 965-984.

Olszak, M., Pipień, M., Kowalska, I., and Roszkowska, S. (2017). What Drives Heterogeneity of Cyclicality of Loan-Loss Provisions in the EU? Journal of Financial Services Research, Vol 51 No.1, pp. 55-96.

Outa, E. R., Ozili, P., and Eisenberg, P. (2017). IFRS convergence and revisions: value relevance of accounting information from East Africa. Journal of Accounting in Emerging Economies, Vol. 7 No. 3, pp. 352-368.

Ozili, P. K. (2015). Loan loss provisioning, income smoothing, signalling, capital management and procyclicality: Does IFRS matter? Empirical evidence from Nigeria. Mediterranean Journal of Social Science, Vol 6 No. 2, pp. 224-232.

Ozili, P. K., and Outa, E. (2017). Bank loan loss provisions research: A review. Borsa Istanbul Review, Vol 17, No 3, pp 144-163. 
Ozili, P. K., and Uadiale, O. (2017). Ownership concentration and bank profitability. Future Business Journal, Vol. 3 No. 2, pp. 159-171.

Ozili, P. K. (2017a). Discretionary provisioning practices among Western European banks. Journal of Financial Economic Policy, Vol 9 No. 1, pp. 109-118.

Ozili, P. K. (2017b). Bank earnings smoothing, audit quality and procyclicality in Africa: The case of loan loss provisions. Review of Accounting and Finance, Vol. 16 No. 2, pp. 142-161.

Ozili, P. K. (2017c). Bank Income Smoothing and Loan Loss Provisioning Practices in Africa (Doctoral dissertation, University of Essex).

Ozili, P. K. (2017d). Bank earnings management and income smoothing using commission and fee income: A European context. International Journal of Managerial Finance, Vol. 13 No. 4, pp. 419439.

Ozili, P. K. (2017e), "Bank profitability and capital regulation: Evidence from listed and non-listed banks in Africa", Journal of African Business, Vol. 18 No.2, pp. 143-168.

Ozili, P.K. and Thankom, A.G. (2018). Income smoothing among European systemic and non-systemic banks. The British Accounting Review. Available at: https://doi.org/10.1016/j.bar.2018.03.001

Ozili, P.K. (2018a). Bank Loan Loss Provisions, Risk-Taking and Bank Intangibles. Afro-Asian Journal of Finance and Accounting, Forthcoming

Ozili, P.K. (2018b), Bank loan loss provisions, investor protection and the macroeconomy", International Journal of Emerging Markets, Vol. 13 No 1, pp.45-65, https://doi.org/10.1108/IJoEM$\underline{12-2016-0327}$

Ozili, P. K. (2018c), "Banking Stability Determinants in Africa", International Journal of Managerial Finance, Forthcoming

La Porta, R., Lopez-de-Silanes, F., and Shleifer, A. (1999). Corporate ownership around the world. The Journal of Finance, Vol 54 No. 2, pp. 471-517.

Plantin, G. (2014), "Shadow banking and bank capital regulation", The Review of Financial Studies, Vol. 28 No. 1, pp. 146-175.

PWC (2010). Reinforcing collective strength and stability South Africa - Major Banks Analysis. Available at: : https://www.pwc.co.za/en/assets/pdf/major-banks-analysis-march-2011.pdf

Shleifer, A., and Vishny, R. W. (1997). A survey of corporate governance. The Journal of Finance, Vol 52 No 2, pp. 737-783.

Shleifer, A., and Wolfenzon, D. (2002). Investor protection and equity markets. Journal of Financial Economics, Vol 66 No. 1, pp. 3-27.

Skała, D. (2015). Saving on a Rainy Day? Income Smoothing and Procyclicality of Loan-Loss Provisions in Central European Banks. International Finance, Vol. 18 No. 1, pp. 25-46.

Wall, L and T Koch (2000) "Bank Loan-Loss Accounting: A Review of Theoretical and Empirical Evidence,” Economic Review, Federal Reserve Bank of Atlanta, Vol 85 No.2, pp 1-19.

Watts, R. L., and Zimmerman, J. L. (1978). Towards a positive theory of the determination of accounting standards. The Accounting Review, Vol. 53, No. 1, pp. 112-134. 
Watts, R. L., and Zimmerman, J. L. (1990). Positive accounting theory: a ten-year perspective. The Accounting Review, Vol. 65, No. 1, pp. 131-156

Watts, R., and Zimmerman. J. (1986). Positive Accounting Theory. Prentice-Hall, Englewood Cliffs, NJ.

Wetmore, J. L., and Brick, J. R. (1994). Loan-loss provisions of commercial banks and adequate disclosure: A note. Journal of Economics and Business, Vol. 46 No 4, pp. 299-305.

Wu, M. W., Shen, C. H., and Lu, C. H. (2015). Do more foreign strategic investors and more directors improve the earnings smoothing? The case of China. International Review of Economics and Finance, Vol 36, pp. 3-16. 


\section{List of Tables}

Table 1

\begin{tabular}{|c|c|c|c|c|c|c|c|}
\hline & (1) & (2) & (3) & $\mathrm{C}_{1}$ & & & \\
\hline $\mathrm{C}$ & $\begin{array}{c}0.134 * * \\
(1.99)\end{array}$ & $\begin{array}{c}0.137 * * \\
(1.98)\end{array}$ & $\begin{array}{c}0.132 * \\
(1.90)\end{array}$ & $\begin{array}{c}0.133^{* *} \\
(2.01)\end{array}$ & $\begin{array}{c}0.155^{* *} \\
(2.25)\end{array}$ & $\begin{array}{c}0.137 * * \\
(2.02)\end{array}$ & $\begin{array}{c}0.132 * * * \\
(2.01)\end{array}$ \\
\hline EBTP & $\begin{array}{l}0.046 \\
(0.47)\end{array}$ & $\begin{array}{l}0.092 \\
(1.27)\end{array}$ & $\begin{array}{c}-0.001 \\
(-0.004)\end{array}$ & $\begin{array}{l}0.033 \\
(0.33) \\
\end{array}$ & $\begin{array}{l}0.044 \\
(0.44)\end{array}$ & $\begin{array}{l}0.025 \\
(0.23)\end{array}$ & $\begin{array}{l}0.025 \\
(0.23)\end{array}$ \\
\hline LOTA & $\begin{array}{c}0.008 * \\
(1.82)\end{array}$ & $\begin{array}{c}0.007 * \\
(1.74)\end{array}$ & $\begin{array}{c}0.009 * \\
(1.77)\end{array}$ & $\begin{array}{c}0.009 * * \\
(2.12)\end{array}$ & $\begin{array}{c}0.012 * * \\
(2.33)\end{array}$ & $\begin{array}{c}0.009 * * \\
(2.09)\end{array}$ & $\begin{array}{c}0.009 * * \\
(2.09)\end{array}$ \\
\hline NPL & $\begin{array}{c}0.135 * * * \\
(2.71)\end{array}$ & $\begin{array}{c}0.137 * * * \\
(2.74)\end{array}$ & $\begin{array}{c}0.134 * * * \\
(2.66)\end{array}$ & $\begin{array}{c}0.134 * * * \\
(2.72)\end{array}$ & $\begin{array}{c}0.137 * * * \\
(2.77)\end{array}$ & $\begin{array}{c}0.136^{* * *} \\
(2.75)\end{array}$ & $\begin{array}{c}0.133 * * * \\
(2.68)\end{array}$ \\
\hline LOAN & $\begin{array}{l}-0.002 \\
(-0.38)\end{array}$ & $\begin{array}{c}0.007^{*} \\
(1.74)\end{array}$ & $\begin{array}{l}-0.002 \\
(-0.39)\end{array}$ & $\begin{array}{l}-0.002 \\
(-0.40)\end{array}$ & $\begin{array}{l}-0.002 \\
(-0.43)\end{array}$ & $\begin{array}{l}-0.002 \\
(-0.37)\end{array}$ & $\begin{array}{l}-0.002 \\
(-0.44)\end{array}$ \\
\hline CAP & $\begin{array}{c}-0.037 * * * \\
(-2.94)\end{array}$ & $\begin{array}{c}-0.035 * * * \\
(-2.79)\end{array}$ & $\begin{array}{c}-0.035 * * * \\
(-2.72)\end{array}$ & $\begin{array}{c}-0.039 * * * \\
(-2.95)\end{array}$ & $\begin{array}{c}-0.032 * * * \\
(-2.66)\end{array}$ & $\begin{array}{c}-0.038 * * * \\
(-2.97)\end{array}$ & $\begin{array}{c}-0.037 * * * \\
(-2.84)\end{array}$ \\
\hline SIZE & $\begin{array}{c}-0.008 * \\
(-1.89)\end{array}$ & $\begin{array}{c}-0.008 * \\
(-1.86)\end{array}$ & $\begin{array}{c}-0.008^{*} \\
(-1.82)\end{array}$ & $\begin{array}{c}-0.009 * \\
(-1.90)\end{array}$ & $\begin{array}{c}-0.009 * * \\
(-2.16)\end{array}$ & $\begin{array}{c}-0.008^{*} \\
(-1.92)\end{array}$ & $\begin{array}{c}-0.008 * \\
(-1.89)\end{array}$ \\
\hline$\Delta \mathrm{GDP}$ & $\begin{array}{c}-0.079 * * * \\
(-2.90)\end{array}$ & $\begin{array}{c}-0.079 * * * \\
(-2.88)\end{array}$ & $\begin{array}{c}-0.080 * * * \\
(-2.92)\end{array}$ & $\begin{array}{l}-0.040 \\
(-1.50)\end{array}$ & $\begin{array}{c}-0.172 * * * \\
(-4.16)\end{array}$ & $\begin{array}{l}-0.041 \\
(-1.51)\end{array}$ & $\begin{array}{l}-0.044 \\
(-1.62)\end{array}$ \\
\hline HIGH & & $\begin{array}{l}0.003 \\
(0.71)\end{array}$ & & & & $\begin{array}{l}0.001 \\
(0.87)\end{array}$ & \\
\hline HIGH*EBTP & & $\begin{array}{l}-0.062 \\
(-0.54)\end{array}$ & & & & & \\
\hline POS & & & $\begin{array}{l}0.003 \\
(1.19)\end{array}$ & & & & $\begin{array}{l}0.002 \\
(0.70)\end{array}$ \\
\hline POS*EBTP & & & $\begin{array}{l}0.037 \\
(0.16)\end{array}$ & & & & \\
\hline BOOM & & & & $\begin{array}{l}-0.003 \\
(-0.94)\end{array}$ & & $\begin{array}{c}-0.003 * * \\
(-2.49)\end{array}$ & $\begin{array}{c}-0.003 * * \\
(-2.51)\end{array}$ \\
\hline BOOM*EBTP & & & & $\begin{array}{l}0.027 \\
(0.94)\end{array}$ & & & \\
\hline REC & & & & & $\begin{array}{c}-0.006 * * \\
(-2.48)\end{array}$ & & \\
\hline REC*EBTP & & & & & $\begin{array}{l}-0.021 \\
(-0.54)\end{array}$ & & \\
\hline BOOM*HIGH*EBTP & & & & & & $\begin{array}{c}0.087 * * \\
(2.42)\end{array}$ & \\
\hline BOOM*POS*EBTP & & & & & & & $\begin{array}{l}0.027 \\
(0.95)\end{array}$ \\
\hline Adjusted $\mathrm{R}^{2}$ & 94.49 & 94.47 & 94.46 & 94.56 & 94.61 & 94.56 & 94.56 \\
\hline F-statistic & 106.85 & 100.77 & 100.53 & 102.64 & 103.63 & 99.95 & 99.68 \\
\hline Durbin Watson & 1.77 & 1.78 & 1.76 & 1.83 & 1.87 & 1.84 & 1.83 \\
\hline Observations & 223 & 223 & 223 & 223 & 223 & 223 & 223 \\
\hline $\begin{array}{l}\text { T-Statistics are reported } \\
\text { estimated using OLS estir } \\
\text { issues. POS is a dummy } \\
\text { value } 1 \text { if EBTP is above- } \\
\text { zero otherwise, representi } \\
\text { above-the-median EBTP } \\
\text { previously defined. }\end{array}$ & $\begin{array}{l}\text { entheses. }{ }^{* *} \\
\text { r with bank } \\
\text { ole that take } \\
\text { median EBT } \\
\text { conomic doy } \\
\text { zero otherwi }\end{array}$ & $\begin{array}{l}* *, * \text { indicat } \\
\text { ed effect. St } \\
\text { value } 1 \text { if } \mathrm{E} \\
\text { and zero oth } \\
\text { urns or rece } \\
\text { representing }\end{array}$ & $\begin{array}{l}\text { gnificance at } \\
\text { Ird errors are } \\
\mathrm{P} \text { is positive } \\
\text { se. REC is a } \\
\text { nary periods } \\
\text { riods of econ }\end{array}$ & $\begin{array}{l}0.01,0.05, \\
\text { stered by bar } \\
\text { zero otherw } \\
\text { amy variable } \\
\text { OM is a dur } \\
\text { c upturns or }\end{array}$ & $\begin{array}{l}0.10 \text { level, } \\
\text { and year and } \\
\text { HIGH is a } \\
\text { at take the v } \\
\text { y variable tl } \\
\text { oms. Other t }\end{array}$ & $\begin{array}{l}\text { ectively. All } \\
\text { robust to he } \\
\text { my variable } \\
\text { e } 1 \text { if } \Delta \text { GDP } \\
\text { take the value } \\
k \text { level variab }\end{array}$ & $\begin{array}{l}\text { ressions are } \\
\text { scedasticity } \\
\text { take the } \\
\text { egative and } \\
\mathrm{f} \Delta \mathrm{GDP} \text { is } \\
\text { remain as }\end{array}$ \\
\hline
\end{tabular}


Table 2

\begin{tabular}{|c|c|c|c|c|c|c|c|}
\hline \multicolumn{8}{|c|}{ Table 2: Ownership Structure, Audit Quality, Financial Crisis and Capital Market Incentive } \\
\hline & (1) & (2) & (3) & (4) & (5) & (6) & (7) \\
\hline $\mathrm{C}$ & $\begin{array}{l}-0.103 \\
(-1.31)\end{array}$ & $\begin{array}{c}-0.017 * * \\
(-2.00)\end{array}$ & $\begin{array}{c}-0.017 * * \\
(-2.21)\end{array}$ & $\begin{array}{c}0.036^{* * *} \\
(2.83)\end{array}$ & $\begin{array}{c}0.015^{*} \\
(1.95)\end{array}$ & $\begin{array}{c}-0.011^{*} \\
(-1.76)\end{array}$ & $\begin{array}{l}-0.013 \\
(-1.64)\end{array}$ \\
\hline EBTP & $\begin{array}{c}0.377 \text { *** } \\
(5.84) \\
\end{array}$ & $\begin{array}{c}0.393^{* * * *} \\
(8.21) \\
\end{array}$ & $\begin{array}{c}0.409^{* * *} \\
(7.66) \\
\end{array}$ & $\begin{array}{l}-0.084 \\
(-0.43) \\
\end{array}$ & $\begin{array}{c}0.188^{*} \\
(1.78) \\
\end{array}$ & $\begin{array}{c}0.386^{* * * *} \\
(8.29) \\
\end{array}$ & $\begin{array}{c}0.362 * * * \\
(4.65) \\
\end{array}$ \\
\hline LOTA & $\begin{array}{l}0.006 \\
(1.39)\end{array}$ & $\begin{array}{c}0.009 * * \\
(2.06)\end{array}$ & $\begin{array}{c}0.008^{*} \\
(1.92)\end{array}$ & $\begin{array}{c}0.013 * * * \\
(3.14)\end{array}$ & $\begin{array}{c}0.014 * * * \\
(3.95)\end{array}$ & $\begin{array}{l}0.007 \\
(0.83)\end{array}$ & $\begin{array}{c}0.008^{* * *} \\
(2.05)\end{array}$ \\
\hline NPL & $\begin{array}{c}0.197 * * * \\
(3.73)\end{array}$ & $\begin{array}{c}0.195^{* * * *} \\
(3.85) \\
\end{array}$ & $\begin{array}{c}0.196^{* * * *} \\
(3.69) \\
\end{array}$ & $\begin{array}{c}0.180^{* * * *} \\
(3.74)\end{array}$ & $\begin{array}{c}0.182 * * * * \\
(3.80)\end{array}$ & $\begin{array}{c}0.202 * * * * \\
(4.20)\end{array}$ & $\begin{array}{c}0.187 * * * * \\
(3.81)\end{array}$ \\
\hline LOAN & $\begin{array}{l}0.014 \\
(1.36) \\
\end{array}$ & $\begin{array}{l}0.012 \\
(1.13)\end{array}$ & $\begin{array}{l}0.013 \\
(1.24)\end{array}$ & $\begin{array}{l}0.008 \\
(0.99)\end{array}$ & $\begin{array}{l}0.005 \\
(0.57)\end{array}$ & $\begin{array}{l}0.007 \\
(0.83)\end{array}$ & $\begin{array}{l}0.007 \\
(0.88) \\
\end{array}$ \\
\hline CAP & $\begin{array}{c}-0.044 * * * \\
(-3.70) \\
\end{array}$ & $\begin{array}{c}-0.044 * * * \\
(-3.71) \\
\end{array}$ & $\begin{array}{c}-0.043 * * * \\
(-3.53) \\
\end{array}$ & $\begin{array}{c}-0.069 * * * \\
(-5.44) \\
\end{array}$ & $\begin{array}{c}-0.059 * * * \\
(-4.24) \\
\end{array}$ & $\begin{array}{c}-0.048 * * * \\
(-4.39) \\
\end{array}$ & $\begin{array}{c}-0.043 * * * \\
(-3.87) \\
\end{array}$ \\
\hline SIZE & $\begin{array}{c}0.0005 \\
(1.16)\end{array}$ & $\begin{array}{c}0.0007^{*} \\
(1.69)\end{array}$ & $\begin{array}{c}0.0006 \\
(1.43)\end{array}$ & $\begin{array}{c}-0.0003 \\
(-0.85)\end{array}$ & $\begin{array}{c}-0.0001 \\
(-0.26)\end{array}$ & $\begin{array}{c}0.0006^{*} \\
(1.70)\end{array}$ & $\begin{array}{c}0.0001 \\
(0.15)\end{array}$ \\
\hline$\Delta \mathrm{GDP}$ & $\begin{array}{c}-0.174 * * * * \\
(-2.75) \\
\end{array}$ & $\begin{array}{c}-0.161 * * * \\
(-2.66) \\
\end{array}$ & $\begin{array}{c}-0.166^{* * * *} \\
(-2.62) \\
\end{array}$ & $\begin{array}{c}-0.148 * * * * \\
(-2.72) \\
\end{array}$ & $\begin{array}{c}-0.121^{* *} \\
(-2.41) \\
\end{array}$ & $\begin{array}{c}-0.123 * * \\
(-2.27) \\
\end{array}$ & $\begin{array}{c}0.008^{* * *} \\
(2.06)\end{array}$ \\
\hline DISP & $\begin{array}{c}-0.006^{*} \\
(-1.86)\end{array}$ & & & & & & \\
\hline DISP*EBTP & $\begin{array}{l}0.051 \\
(0.73)\end{array}$ & & & & & & \\
\hline CN1 & & $\begin{array}{c}0.006^{* * *} \\
(2.25)\end{array}$ & & & & & \\
\hline CN1*EBTP & & $\begin{array}{c}-0.464 * * * \\
(-3.99)\end{array}$ & & & & & \\
\hline $\mathrm{CN} 2$ & & & $\begin{array}{l}0.004 \\
(1.58) \\
\end{array}$ & & & & \\
\hline CN2*EBTP & & & $\begin{array}{l}-0.037 \\
(-0.54)\end{array}$ & & & & \\
\hline DQ & & & & $\begin{array}{c}-0.038 * * * \\
(-4.17)\end{array}$ & & & \\
\hline DQ*EBTP & & & & $\begin{array}{c}0.525^{* *} \\
(2.57) \\
\end{array}$ & & & \\
\hline BIG4 & & & & & $\begin{array}{c}-0.023 * * * \\
(-4.94) \\
\end{array}$ & & \\
\hline BIG4*EBTP & & & & & $\begin{array}{c}0.250^{* *} \\
(2.43)\end{array}$ & & \\
\hline LISTED & & & & & & $\begin{array}{c}-0.009^{* * *} \\
(-3.12) \\
\end{array}$ & \\
\hline LISTED*EBTP & & & & & & $\begin{array}{l}0.053 \\
(0.91)\end{array}$ & \\
\hline CRISIS & & & & & & & $\begin{array}{l}0.005 \\
(1.61) \\
\end{array}$ \\
\hline CRISIS*EBTP & & & & & & & $\begin{array}{l}0.054 \\
(0.65)\end{array}$ \\
\hline Adjusted $\mathrm{R}^{2}$ & 77.90 & 77.96 & 77.78 & 80.26 & 80.96 & 79.51 & 79.48 \\
\hline F-statistic & 73.86 & 73.84 & 73.36 & 99.96 & 105.92 & 92.85 & 96.57 \\
\hline Durbin Watson & 0.93 & 0.92 & 0.92 & 1.01 & 0.98 & 0.93 & 0.92 \\
\hline Observations & 187 & 187 & 187 & 220 & 223 & 214 & 223 \\
\hline $\begin{array}{l}\text { T-Statistics are repor } \\
\text { regressions are estim } \\
\text { dummy variables anc } \\
\text { heteroscedasticity iss } \\
\text { equity holding and z } \\
\text { takes the value of on } \\
\text { representing banks w } \\
\text { shareholder has at lea } \\
\text { ownership. BIG4 is a } \\
\text { dummy variable that } \\
\text { the bank adopts IFRS } \\
\text { (i.e., 2009, 2010, } 201\end{array}$ & $\begin{array}{l}\text { parentheses. } \\
\text { sing OLS est } \\
\text { ank fixed eff } \\
\text { ISP is a dun } \\
\text { erwise, repr } \\
\text { najority shar } \\
\text { dium or moc } \\
\text { \% direct equi } \\
\text { ny variable t } \\
\text { he value one } \\
\text { lards and zer } \\
\text { 2, } 2013 \text { and }\end{array}$ & $\begin{array}{l}*, * *, * \text { indic } \\
\text { ator. Bank fi } \\
\text { dummy. Sta } \\
\text { yariable th. } \\
\text { ating banks } \\
\text { lder has at le } \\
\text { ate ownershi } \\
\text { holdings (i.e. } \\
\text { take the val } \\
\text { he bank is li } \\
\text { therwise. CR } \\
\text { 14) and zero }\end{array}$ & $\begin{array}{l}\text { significanc } \\
\text { effect is no } \\
\text { ard errors ar } \\
\text { ake the valu } \\
\text { h a more dis } \\
40 \% \text { but le } \\
\text { ontrol. CN2 } \\
\% \text { to } 100 \%) \\
\text { of one if the } \\
\text { d and zero o } \\
\text { IS is a dumr } \\
\text { eerwise. Oth }\end{array}$ & $\begin{array}{l}t \text { the } 0.01,0 . \\
\text { cluded due } t \\
\text { lustered by b } \\
\text { f one if no m } \\
\text { sed ownersh } \\
\text { han } 70 \% \text { of } \\
\text { a dummy var } \\
\text { d zero other } \\
\text { nk has a Big } \\
\text { rwise. DQ is } \\
\text { variable that } \\
\text { bank level va }\end{array}$ & $\begin{array}{l}\text { and } 0.10 \text { le } \\
\text { refect collin } \\
\mathrm{k} \text { and year a } \\
\text { rity shareho } \\
\text { structure. CI } \\
\text { ect equity ho } \\
\text { le that take } \\
\text { e, representi } \\
\text { uditor and } \mathrm{z} \\
\text { dummy vari } \\
\text { ke the value } \\
\text { bles remain }\end{array}$ & $\begin{array}{l}\text {, respectivel } \\
\text { rity between } \\
\text { are robust to } \\
\text { r holds at le: } \\
\text { is a dummy } \\
\text { ings and zerc } \\
\text { value of on } \\
\text { banks with } \\
\text { otherwise. } \\
\text { e that take th } \\
\text { or the post-c } \\
\text { previously d }\end{array}$ & $\begin{array}{l}\text { all } \\
\text { bank-type } \\
40 \% \text { direct } \\
\text { iable that } \\
\text { herwise, } \\
\text { a majority } \\
\text { centrated } \\
\text { TED is a } \\
\text { alue one if } \\
\text { s period } \\
\text { ned. }\end{array}$ \\
\hline
\end{tabular}


Table 3

\begin{tabular}{|c|c|c|c|c|c|c|}
\hline \multicolumn{7}{|c|}{ Table 3: Bank Income Smoothing Incremental to Bank Capital and Credit Risk } \\
\hline & (1) & (2) & (3) & (4)) & (5) & (6) \\
\hline $\mathrm{C}$ & $\begin{array}{l}0.059^{*} \\
(1.65)\end{array}$ & $\begin{array}{l}0.114 * \\
(-1.74)\end{array}$ & $\begin{array}{l}0.109^{*} \\
(1.76)\end{array}$ & $\begin{array}{l}0.102 * \\
(1.65)\end{array}$ & $\begin{array}{c}0.161 * * \\
(2.37)\end{array}$ & $\begin{array}{c}0.154 * * \\
(2.29)\end{array}$ \\
\hline EBTP & $\begin{array}{c}0.172 * * * \\
(3.33)\end{array}$ & $\begin{array}{l}0.071 \\
(0.69) \\
\end{array}$ & $\begin{array}{c}0.049 * * * \\
(2.66)\end{array}$ & $\begin{array}{l}0.057 \\
(0.63) \\
\end{array}$ & $\begin{array}{l}-0.084 \\
(-0.43) \\
\end{array}$ & $\begin{array}{l}0.045 \\
(0.47) \\
\end{array}$ \\
\hline LOTA & $\begin{array}{l}0.005 \\
(1.39) \\
\end{array}$ & $\begin{array}{c}0.009^{* *} \\
(1.99)\end{array}$ & $\begin{array}{c}0.009^{* *} \\
(2.07)\end{array}$ & $\begin{array}{c}0.011 * * \\
(2.25)\end{array}$ & $\begin{array}{c}0.013^{* * * *} \\
(3.14)\end{array}$ & $\begin{array}{c}0.012 * * \\
(2.34)\end{array}$ \\
\hline NPL & $\begin{array}{c}0.148 * * \\
(2.51)\end{array}$ & $\begin{array}{c}0.139 * * * \\
(2.95) \\
\end{array}$ & $\begin{array}{c}0.131 * * * \\
(2.64) \\
\end{array}$ & $\begin{array}{c}0.132 * * * \\
(2.68) \\
\end{array}$ & $\begin{array}{c}0.138 * * * \\
(2.77) \\
\end{array}$ & $\begin{array}{c}0.137 * * \\
(2.23) \\
\end{array}$ \\
\hline LOAN & $\begin{array}{l}-0.003 \\
(-0.45)\end{array}$ & $\begin{array}{l}-0.006 \\
(-1.04) \\
\end{array}$ & $\begin{array}{l}-0.002 \\
(-0.37)\end{array}$ & $\begin{array}{l}-0.003 \\
(-0.52) \\
\end{array}$ & $\begin{array}{l}-0.003 \\
(-0.55) \\
\end{array}$ & $\begin{array}{l}-0.002 \\
(-0.43) \\
\end{array}$ \\
\hline CAP & $\begin{array}{c}-0.034 * * * \\
(-2.82) \\
\end{array}$ & $\begin{array}{c}-0.043 * * * \\
(-3.26) \\
\end{array}$ & $\begin{array}{c}-0.048 * * * \\
(-2.66) \\
\end{array}$ & $\begin{array}{c}-0.052 * * * \\
(-2.94) \\
\end{array}$ & $\begin{array}{l}-0.033 \\
(-2.53) \\
\end{array}$ & $\begin{array}{c}-0.032 * * * \\
(-2.67) \\
\end{array}$ \\
\hline SIZE & $\begin{array}{l}-0.003 \\
(-1.43)\end{array}$ & $\begin{array}{c}0.007 \\
(-1.64)\end{array}$ & $\begin{array}{l}-0.006 \\
(-1.62)\end{array}$ & $\begin{array}{l}-0.006 \\
(-1.51) \\
\end{array}$ & $\begin{array}{c}-0.009^{* *} \\
(-2.26)\end{array}$ & $\begin{array}{c}-0.009^{* *} \\
(-2.20)\end{array}$ \\
\hline$\Delta \mathrm{GDP}$ & $\begin{array}{c}-0.082 * * * \\
(-2.68)\end{array}$ & $\begin{array}{c}-0.061 * * \\
(-2.41)\end{array}$ & $\begin{array}{c}-0.084 * * * \\
(-3.18)\end{array}$ & $\begin{array}{l}-0.049^{*} \\
(-1.89)\end{array}$ & $\begin{array}{c}-0.165 * * * \\
(-4.06)\end{array}$ & $\begin{array}{c}-0.173 * * * \\
(-4.03)\end{array}$ \\
\hline DB & $\begin{array}{l}0.008 \\
(1.02)\end{array}$ & & & & & $\begin{array}{c}0.0001 \\
(0.02)\end{array}$ \\
\hline DB*EBTP & $\begin{array}{l}-0.293^{*} \\
(-1.87) \\
\end{array}$ & & & & & \\
\hline $\mathrm{UC}$ & & $\begin{array}{l}0.005 \\
(1.51) \\
\end{array}$ & & & $\begin{array}{l}-0.001 \\
(-0.43) \\
\end{array}$ & \\
\hline $\mathrm{UC} * \mathrm{EBTP}$ & & $\begin{array}{l}-0.114^{*} \\
(-1.92) \\
\end{array}$ & & & & \\
\hline WC & & & $\begin{array}{l}-0.002 \\
(-0.64) \\
\end{array}$ & & & \\
\hline WC*EBTP & & & $\begin{array}{c}0.066^{*} \\
(1.68)\end{array}$ & & & \\
\hline BOOM & & & & $\begin{array}{c}-0.002^{*} \\
(-1.78) \\
\end{array}$ & & \\
\hline REC & & & & & $\begin{array}{c}-0.008 * * * \\
(-2.92) \\
\end{array}$ & $\begin{array}{c}-0.007 * * * * \\
(-3.16) \\
\end{array}$ \\
\hline $\mathrm{BOOM} * \mathrm{WC} * \mathrm{EBTP}$ & & & & $\begin{array}{c}0.073^{* * *} \\
(2.05) \\
\end{array}$ & & \\
\hline REC*UC*EBTP & & & & & $\begin{array}{l}0.040 \\
(0.54)\end{array}$ & \\
\hline Adjusted $\mathrm{R}^{2}$ & 95.13 & 94.71 & 94.54 & 94.67 & 94.58 & 94.61 \\
\hline F-statistic & 115.04 & 105.65 & 102.23 & 102.18 & 100.44 & 100.84 \\
\hline Durbin Watson & 1.96 & 1.72 & 1.82 & 1.82 & 1.86 & 1.88 \\
\hline Observations & 223 & 223 & 223 & 223 & 223 & 223 \\
\hline
\end{tabular}

T-Statistics are reported in parentheses. ***,**,* indicate significance at the $0.01,0.05$, and 0.10 level,

respectively. All regression is estimated using OLS estimator with bank fixed effect. Standard errors are clustered by bank and year and are robust to heteroscedasticity issues. DB is a dummy variable that take the value of one if NPL ratio is a double-digit number (when expressed in percentage) and zero otherwise, reflecting periods of significant credit losses or loan loss. UC is a dummy variable that takes the value of one if CAP ratio is less than $25 \%$ and zero otherwise, representing periods when banks are undercapitalized. WC is a dummy variable that takes the value of one when CAP ratio is at least $50 \%$ and zero otherwise, representing periods when banks are wellcapitalised. REC is a dummy variable takes the value one if $\triangle \mathrm{GDP}$ is negative and zero otherwise, representing economic downturns or recessionary periods. BOOM is a dummy variable that take the value one if $\Delta$ GDP is above-the-median EBTP and zero otherwise, representing economic upturns or booms. Other bank level variables remain as previously defined. 


\section{Appendix}

\begin{tabular}{|l|l|l|l|l|l|l|l|l|l|}
\hline \multicolumn{7}{|c|}{ A1: Summary of Descriptive statistics } \\
\hline $\begin{array}{l}\text { Table 1 reports the descriptive statistics obtained from 30 banks in South Africa. Data cover 2002-2014 } \\
\text { period. LLP is loan loss provisions. NPL is non-performing loans. EBTP is earnings before taxes and } \\
\text { provisions. LOAN is change in gross loan outstanding. CAP is capital ratio. LOTA is loan to asset ratio. } \\
\Delta \text { GDP is gross domestic product growth rate. SIZE is the natural logarithm of bank total asset. }\end{array}$ \\
\hline & LLP & EBTP & NPL & LOTA & LOAN & CAP & SIZE & $\Delta$ GDP \\
\hline Mean & 0.022 & 0.056 & 0.055 & 0.707 & 0.172 & 0.215 & 14.70 & 0.032 \\
\hline Median & 0.006 & 0.026 & 0.027 & 0.696 & 0.143 & 0.153 & 13.53 & 0.032 \\
\hline Standard deviation & 0.039 & 0.072 & 0.088 & 0.258 & 0.201 & 0.177 & 2.49 & 0.018 \\
\hline Maximum & 0.221 & 0.409 & 0.875 & 1.439 & 0.973 & 0.973 & 19.12 & 0.056 \\
\hline Minimum & -0.007 & -0.032 & 0.004 & 0.129 & -0.734 & -0.734 & 9.96 & -0.015 \\
\hline Observation & 276 & 273 & 233 & 3226 & 269 & 269 & 304 & 390 \\
\hline Note: The statistics may be expressed in percentages for expositional convenience & & \\
\hline
\end{tabular}


A2: Correlation Matrix

\begin{tabular}{|c|c|c|c|c|c|c|c|c|}
\hline Variables & LLP & EBTP & NPL & LOTA & LOAN & CAP & SIZE & $\Delta \mathrm{GDP}$ \\
\hline LLP & 1.000 & & & & & & & \\
\hline EBTP & $\begin{array}{r}0.786^{* * * *} \\
0.000\end{array}$ & 1.000 & & & & & & \\
\hline NPL & $\begin{array}{r}0.657 * * * \\
0.000\end{array}$ & $\begin{array}{r}0.436^{* * * *} \\
0.000\end{array}$ & 1.000 & & & & & \\
\hline LOTA & $\begin{array}{r}0.436^{* * * *} \\
0.000\end{array}$ & $\begin{array}{r}0.363 * * * \\
0.000\end{array}$ & $\begin{array}{r}0.307^{* * * *} \\
0.000\end{array}$ & 1.000 & & & & \\
\hline LOAN & $\begin{array}{r}0.384 * * * \\
0.000\end{array}$ & $\begin{array}{r}0.519^{* * * *} \\
0.000\end{array}$ & $\begin{array}{l}0.103 \\
0.122\end{array}$ & $\begin{array}{r}0.309^{* * * *} \\
0.000\end{array}$ & 1.000 & & & \\
\hline CAP & $\begin{array}{r}0.298 * * * \\
0.000\end{array}$ & $\begin{array}{r}0.551^{* * * *} \\
0.000\end{array}$ & $\begin{array}{r}0.340^{* * * *} \\
0.000\end{array}$ & $\begin{array}{r}0.124 * \\
0.064\end{array}$ & $\begin{array}{r}0.231^{* * * *} \\
0.000\end{array}$ & 1.000 & & \\
\hline SIZE & $\begin{array}{r}-0.057 \\
0.390\end{array}$ & $\begin{array}{r}-0.195^{* * * *} \\
0.003\end{array}$ & $\begin{array}{r}-0.071 \\
0.288\end{array}$ & $\begin{array}{r}0.0714 \\
0.288\end{array}$ & $\begin{array}{r}-0.150 * * \\
0.020\end{array}$ & $\begin{array}{r}-0.469 * * * \\
0.000\end{array}$ & 1.000 & \\
\hline$\Delta \mathrm{GDP}$ & $\begin{array}{r}-0.108 \\
0.105\end{array}$ & $\begin{array}{l}0.020 \\
0.760\end{array}$ & $\begin{array}{r}-0.177 * * * \\
0.007\end{array}$ & $\begin{array}{r}-0.019 \\
0.768\end{array}$ & $\begin{array}{r}0.381 * * * \\
0.000\end{array}$ & $\begin{array}{r}-0.057 \\
0.390\end{array}$ & $\begin{array}{l}0.048 \\
0.467\end{array}$ & 1.000 \\
\hline
\end{tabular}

\begin{tabular}{|c|c|c|c|c|c|c|c|c|c|}
\hline \multicolumn{10}{|c|}{ A3: Sample Distribution } \\
\hline Country & \# & $\begin{array}{l}\text { Listed } \\
\text { banks }\end{array}$ & $\begin{array}{l}\text { Unlisted } \\
\text { banks }\end{array}$ & $\begin{array}{l}\text { Big-4 } \\
\text { auditor } \\
\text { Banks }\end{array}$ & $\begin{array}{c}\text { Non-big } 4 \\
\text { auditor banks }\end{array}$ & $\begin{array}{c}\text { Banks with } \\
\text { dispersed } \\
\text { Ownership } \\
(<40)\end{array}$ & $\begin{array}{c}\text { Banks with a } \\
\text { majority } \\
\text { shareholder } \\
(40-69 \%)\end{array}$ & $\begin{array}{c}\text { Banks with a } \\
\text { majority } \\
\text { shareholder } \\
(\geq 70)\end{array}$ & $\begin{array}{c}\text { No of Bank that } \\
\text { adopt IFRS }\end{array}$ \\
\hline South Africa & 30 & 10 & 20 & 27 & 3 & 7 & 4 & 13 & 28 \\
\hline & & & & & & & & & \\
\hline
\end{tabular}


A4. Correlation Matrix: Dummy variables

\begin{tabular}{|c|c|c|c|c|c|c|c|}
\hline Dummies & REC & BOOM & WC & UC & HIGH & DB & POS \\
\hline REC & 1.000 & & & & & & \\
\hline \multirow[t]{2}{*}{ BOOM } & $-0.238 * * *$ & 1.000 & & & & & \\
\hline & 0.000 & & & & & & \\
\hline \multirow[t]{2}{*}{ WC } & 0.067 & 0.049 & 1.000 & & & & \\
\hline & 0.310 & 0.453 & & & & & \\
\hline \multirow[t]{2}{*}{$\mathrm{UC}$} & -0.090 & 0.045 & $-0.398 * * *$ & 1.000 & & & \\
\hline & 0.171 & 0.490 & 0.000 & & & & \\
\hline \multirow[t]{2}{*}{ HIGH } & $0.143^{* *}$ & -0.038 & $0.150 * *$ & $-0.434 * * *$ & 1.000 & & \\
\hline & 0.029 & 0.609 & 0.022 & 0.000 & & & \\
\hline \multirow[t]{2}{*}{ DB } & 0.063 & -0.035 & $0.168 * * *$ & $-0.316^{* * *}$ & $0.321 * * *$ & 1.000 & \\
\hline & 0.333 & 0.588 & 0.010 & 0.000 & 0.000 & & \\
\hline \multirow[t]{2}{*}{ POS } & $-0.144 * *$ & -0.022 & 0.041 & -0.042 & $0.148^{* *}$ & 0.051 & 1.000 \\
\hline & 0.028 & 0.734 & 0.526 & 0.524 & 0.024 & 0.432 & \\
\hline
\end{tabular}




\begin{tabular}{|c|c|c|}
\hline \multicolumn{3}{|c|}{ Appendix A5: Definition of Main Variables } \\
\hline Variable & Description & Source \\
\hline LLP & Ratio of loan loss provisions to beginning total asset & Bankscope \\
\hline NPL & Ratio of non-performing loans to beginning total assets. & Bankscope \\
\hline CAP & Ratio of total equity to beginning total asset. & Bankscope \\
\hline EBTP & Ratio of pre-provisions earnings before tax to beginning total assets. & Bankscope \\
\hline SIZE & Natural logarithm of total asset. & Bankscope \\
\hline LOAN & Loan Growth is change in gross loan outstanding. & Bankscope \\
\hline LOTA & Ratio of total loan to beginning total asset. & Bankscope \\
\hline$\Delta \mathrm{GDP}$ & Growth in real gross domestic product & $\begin{array}{l}\text { World Bank } \\
\text { database }\end{array}$ \\
\hline BIG4 & Bankscope provide information about bank auditor-type. & Bankscope \\
\hline DQ & $\begin{array}{l}\text { Bankscope provide information of accounting standards adopted by } \\
\text { banks }\end{array}$ & Bankscope \\
\hline LISTED & $\begin{array}{l}\text { Bankscope provide information on whether a firm is listed, delisted } \\
\text { or unlisted. }\end{array}$ & Bankscope \\
\hline $\begin{array}{l}\text { DISP, CN1, } \\
\text { CN2 }\end{array}$ & Bankscope provide ownership information of banks & Bankscope \\
\hline
\end{tabular}

